\title{
39. LATE CENOZOIC STABLE ISOTOPIC STRATIGRAPHY, DEEP SEA DRILLING PROJECT SITES 603 AND 604, NORTHEAST AMERICAN CONTINENTAL RISE ${ }^{1}$
}

\author{
Gerald Ganssen, Instituut voor Aardwetenschappen, Vrije Universiteit, Amsterdam²
}

\section{INTRODUCTION}

Holes $603 \mathrm{C}$ and 604 of DSDP Leg 93 were drilled on the western Atlantic continental rise at water depths of $4633 \mathrm{~m}$ and $2364 \mathrm{~m}$, respectively (Fig. 1). In Hole 603C, a nearly continuous, undisturbed, and complete section of Pliocene and lower Pleistocene sediments was recovered by hydraulic piston coring; in Hole 604, a section of uppermost Miocene to Pleistocene sediments was incompletely recovered by rotary coring.

In order to reconstruct the Pliocene and Pleistocene history of isotopic variations, 139 oxygen and carbon isotope values were determined for planktonic and monospecific benthic foraminifer samples from these holes. Large parts of the Pleistocene history could not, however, be documented because sample intervals were large and sediments at Site 604 were redeposited. Time correlation is based on magnetostratigraphic (Hole 603C) and micropaleontologic (Hole 603C, Site 604) interpretation.

Stable isotope analyses were carried out on the planktonic foraminiferal species Globigerinoides ruber, $G$. $o b$ liquus, and Globorotalia inflata from Hole 603C (48 analyses) and from Site 604 (48 analyses); at Site 604, the benthic foraminifer Uvigerina peregrina (43 analyses) was also studied through the section. Age calibration for Hole $603 \mathrm{C}$ is based on the magnetostratigraphy of Canninga et al. (this volume), which uses the time scale of Lowrie and Alvarez (1981).

\section{METHODS}

Samples were boiled in a Calgon solution and washed through a 63- $\mu \mathrm{m}$ sieve (see Moullade, and Ma'alouleh and Moullade, this volume). Planktonic and benthic specimens from the $>160-\mu \mathrm{m}$ fraction were picked under a binocular microscope. Because the preservation of benthic foraminifers differed between samples, we considered cleaning some specimens ultrasonically before isotopic analysis. However, we tested the effect of ultrasonic cleaning on the stable isotopic composition of $U$. peregrina from one sample in which there were both wellpreserved and badly preserved specimens and found that it had no effect and thus was unnecessary (Table 1). Most planktonic specimens were excellently preserved and did not need ultrasonic treatment. Only tests filled with fine calcareous material were ultrasonically cleaned for 1 $\mathrm{min}$. in analytical grade methanol. The carbonate was dissolved with $100 \%$ phosphoric acid in vacuum at $50^{\circ} \mathrm{C}$. Isotopic analyses were carried out offline on a MAT 251 mass spectrometer; 1 to 3 benthic and 5 to 20 planktonic tests provided a sufficient gas pressure.

Standard deviation ( $1 \sigma)$ of repeatedly measured specimens ( 8 measurements) of $U$. peregrina is $\pm 0.12 \%$ for $\delta^{18} \mathrm{O}$ and $\pm 0.04 \%$ for $\delta^{13} \mathrm{C}$

\footnotetext{
${ }^{1}$ van Hinte, J. E., Wise, S. W., Jr., et al., Init. Repts. DSDP, 93: Washington (U.S Govt. Printing Office).

Door Aardwetenschappen, Vrije Universiteit Postbus 7161, 1007 MC Amsterdam, The Netherlands.
}

(see Table 1). Analytical precision of continuously run standards (Solnhofen limestone and "Merck" $100 \% \mathrm{CaCO}_{3}$ ) was $\pm 0.18 \%$ for $\delta^{18} \mathrm{O}$ and $\pm 0.10 \%$ for $\delta^{13} \mathrm{C}(1 \mathrm{\sigma})$ during the period of the measurements.

\section{RESULTS AND DISCUSSIONS}

All measurements are listed in Table 2 and plotted in Figures 2 and 3.

For resolution of the paleoclimatic and paleoceanographic history of these holes, we have used the magnetostratigraphy of Canninga et al. (Hole 603C, this volume), and the biostratigraphic zones of $\mathrm{Ma}$ 'alouleh and Moullade, Moullade (planktonic foraminifers; Hole 603C, Site 604, respectively), Muza et al., and Lang and Wise (nannofossils; Hole 603C, Site 604, respectively).

\section{Hole 603C}

Stable isotopes of three planktonic foraminifers ( $\mathrm{Globi}$ gerinoides ruber, G. obliquus, and Globorotalia inflata) were analyzed from Hole $603 \mathrm{C}$ sediments. Three different stratigraphic units can be distinguished in both oxygen and carbon isotope values.

\section{Unit I (Samples 603C-40-4, 90-94 cm to 603C-24-3, 90-94 cm, CN9-11b, Pl1a-3)}

The deepest sediments recovered in Hole 603C (Core $40)$ are of earliest Pliocene age and show a shift to higher $\delta^{18} \mathrm{O}$ values also observed in isotopic curves from planktonic foraminifera in the Panama Basin (DSDP Site 157; Keigwin, 1979) and on the Sierra Leone Rise (DSDP Site 366; Stein, 1984). The lowest values found by these authors for the latest Miocene are not reached in Hole $603 \mathrm{C}$ and are assumed to occur in the sediments just below total depth of the hole. The top of this unit is identified at the shift to lower values in Core 24. Results from Cores 39 to 24 show a $\delta^{18} \mathrm{O}$ variation of $1.5 \%$ max. that can be interpreted as changes in the Antarctic ice volume, in the temperature of surface waters, or in both.

The carbon isotope values of this unit are characterized by a gradual change from +1.5 to $+3.0 \%$, indicating a slow, continuous change in the $\mathrm{CO}_{2}$ budget of the surface waters. The variation of the values up to $1.5 \% 0$ indicates temporal fluctuations in surface-water productivity.

\section{Unit II (Samples 603C-23-3, 90-94 cm to 603C-15-4,CC, CN11b-12a, P13-4)}

Oxygen isotope values become higher in two steps, one between 3.7 and $3.5 \mathrm{Ma}$ (Cores 23 and 22) and one at $3.0 \mathrm{Ma}$ (Core 15), defining the top of this unit. This 
G. GANSSEN

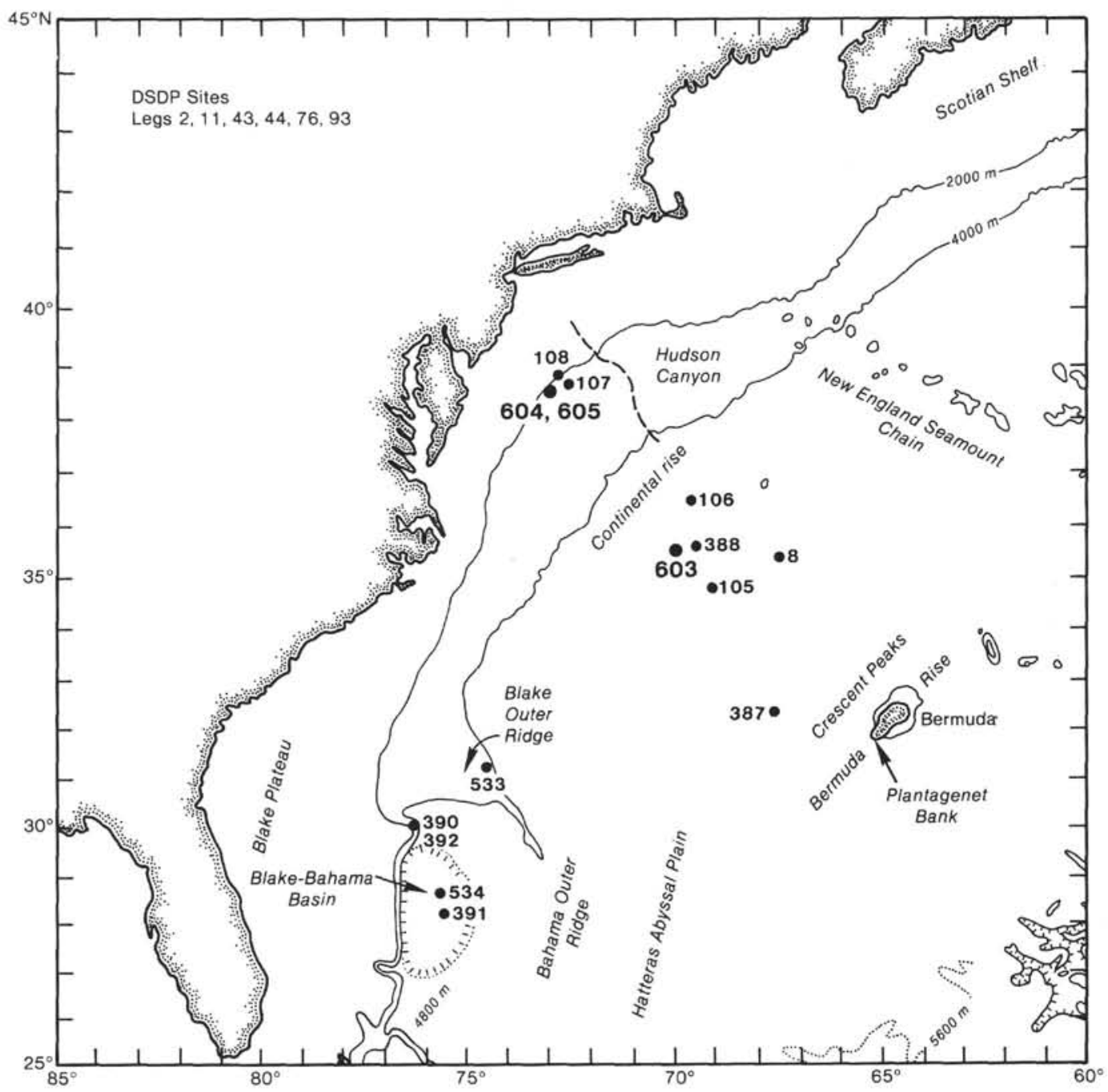

Figure 1. Location of DSDP Sites 603 and 604.

Table 1. Effect of ultrasonic cleaning on the stable isotopic composition of $U$. peregrina from Sample 604-19,CC.

\begin{tabular}{|c|c|c|c|c|}
\hline \multirow[b]{3}{*}{ Treatment } & \multicolumn{4}{|c|}{ Preservation (\%oPDB) } \\
\hline & \multicolumn{2}{|c|}{ Good } & \multicolumn{2}{|c|}{ Poor } \\
\hline & ${ }_{{ }^{18}}^{18 \mathrm{O}}$ & ${ }_{\delta^{13} \mathrm{O}}$ & $\overline{\delta^{18} \mathrm{O}}$ & $\overline{\delta^{13} \mathrm{O}}$ \\
\hline No cleaning & $\begin{array}{l}+2.88 \\
+3.05\end{array}$ & $\begin{array}{l}+0.17 \\
+0.22\end{array}$ & $\begin{array}{r}+2.96 \\
+3.12\end{array}$ & $\begin{array}{l}+0.14 \\
+0.26\end{array}$ \\
\hline $\begin{array}{l}\# 1=\min . \\
\text { ultrasonic } \\
\text { cleaning }\end{array}$ & $\begin{array}{l}+3.00 \\
+3.15\end{array}$ & $\begin{array}{l}+0.25 \\
+0.17\end{array}$ & $\begin{array}{l}+3.13 \\
+2.80\end{array}$ & $\begin{array}{l}+0.26 \\
+0.21\end{array}$ \\
\hline
\end{tabular}

Note: The mean values of the 8 analyses are $3.01+$ $0.12 \% 0(1 \sigma)$ for $\delta^{18} 0$ and $0.20 \pm 0.04 \%$ for $\delta^{13} \mathrm{C}$

stepwise change in the Atlantic Ocean is commonly interpreted as the onset of Northern Hemisphere glaciation (Shackleton and Kennett, 1975; Shackleton and Cita, 1979; Stein, 1984). However, Prell (1984), who studied the interval between 3.6 and $2.8 \mathrm{Ma}$, found these shifts in oxygen isotopes only in benthic, not in plank- tonic, foraminifers from different DSDP sites and piston cores from the Pacific and Indian oceans and the Caribbean Sea. He concluded that these shifts do not mark the onset of Northern Hemisphere glaciation, but rather reflect a cooling of high-latitude surface waters, resulting in the production of colder bottom waters. It seems, however, that all the North Atlantic surface waters were cooled, because Thunell (1979) and Stein (1984) also observed a shift to higher $\delta^{18} \mathrm{O}$ values in planktonic foraminifers in subtropical/tropical cores in the Mediterranean Sea and off West Africa, respectively. This agrees with the results of Backman (1979), who observed the first appearance of ice-rafted material in the North Atlantic Ocean at about $2.5 \mathrm{Ma}$. Also, Shackleton et al. (1984) report that the first major ice-rafting horizon occurs at about 2.4 Ma at DSDP Site 522A (Rockall Plateau).

Between 3.7 and $3.0 \mathrm{Ma}$ the mean of the $\delta^{13} \mathrm{C}$ values stays relatively constant, with short-term fluctuations of about $1 \% 0$. At 3 Ma there occurs a sharp change of nearly $2 \%$ to higher values, indicating a change in surfacewater productivity. 
Table 2. Oxygen and carbon isotope composition of planktonic foraminiferal species from Holes 603 and 604, and one benthic species from Hole 604.

Sample
$\begin{gathered}\text { (interval in } \\ \mathrm{cm})\end{gathered}$$\quad \frac{\delta^{18} \mathrm{O} \delta^{13} \mathrm{C}}{(\% 0 \mathrm{PDB})}$

Hole 603B

Globigerinoides ruber

$\begin{array}{llc}2-3,146-150 & +2.03 & +3.13 \\ 3-3,100-104 & -0.14 & +1.67 \\ 4-3,90-94 & +0.11 & +1.50 \\ 5-3,90-94 & +0.49 & +2.71 \\ 6-3,90-92 & -0.61 & +2.28 \\ 7-3,90-92 & +0.09 & +1.94 \\ 8-3,90-93 & +0.02 & +2.32 \\ 10-3,90-94 & -1.02 & +2.82 \\ 11-2,90-94 & -0.70 & +3.15 \\ 14-3,90-94 & +0.22 & - \\ 15, \text { CC } & -0.56 & +3.34\end{array}$

Globigerinoides obliquus

$\begin{array}{llr}11-2,90-94 & -1.32 & +1.92 \\ 13-2,90-94 & -0.48 & +1.97 \\ 14-3,90-94 & -0.46 & +3.10 \\ 15 \mathrm{cc} & +0.16 & +3.32 \\ 16-3,90-94 & -1.67 & +1.50 \\ 17-3,90-94 & -0.56 & +2.77 \\ 18-3,90-94 & -1.11 & +1.91 \\ 20, \mathrm{CC} & -1.52 & +2.41 \\ 21-3,90-94 & -0.77 & +2.83 \\ 22-3,90-94 & -0.64 & +2.05 \\ 23-3,90-94 & -1.70 & +2.31 \\ 24-3,90-94 & -2.07 & +1.99 \\ 24, C \mathrm{C} & -0.78 & +2.81 \\ 25-3,90-94 & -1.40 & +3.11 \\ 26-3,90-94 & -1.06 & +2.22 \\ 26, C \mathrm{CC} & -1.54 & +2.24 \\ 27-3,90-94 & -1.38 & +2.64 \\ 28-3,90-94 & -1.28 & +2.71 \\ 28, C \mathrm{CC} & -1.01 & +2.30 \\ 29-2,90-94 & -1.83 & +1.91 \\ 30-2,90-94 & -1.47 & +2.72 \\ 30, C \mathrm{CC} & -1.43 & +2.10 \\ 31-3,90-94 & -1.37 & +1.46 \\ 32, \mathrm{CC} & -0.83 & +1.40 \\ 33-3,90-94 & -1.56 & +2.20 \\ 34, \mathrm{CC} & -1.62 & +2.53 \\ 35-3,90-94 & -0.50 & +1.30 \\ 36-3,90-94 & -1.81 & +1.07 \\ 36, C \mathrm{C} & -2.03 & +2.16 \\ 37-3,90-94 & -1.82 & +1.96 \\ 38-3,90-94 & -1.16 & +1.25 \\ 39-3,90-94 & -0.83 & +1.59 \\ 40-3,90-94 & -2.05 & +2.16\end{array}$

Globorotalia inflata

$\begin{array}{lll}2-3,146-150 & +1.82 & +1.79 \\ 3-3,100-104 & +2.54 & +2.43 \\ 4-3,90-94 & +1.39 & +1.62 \\ 5-3,90-94 & +1.53 & +2.55\end{array}$

Hole 604

Globigerinoides ruber

$\begin{array}{llr}1-1,0-1 & -0.80 & +4.21 \\ 3-2,25-26 & -0.03 & +1.98 \\ 4, C C & -0.37 & +1.52 \\ 5, C C & -0.77 & +2.17 \\ 6-5,56-58 & -0.15 & +4.05 \\ 11-3,90-94 & +0.04 & +3.06 \\ 13 c c & -0.60 & +3.13\end{array}$

Table 2 (continued).

Sample
$\begin{gathered}\text { (interval in } \\ \mathrm{cm})\end{gathered}$

Hole 604 (Cont.)

Globigerinoides ruber (Cont.)

$\begin{array}{lll}14-3,90-94 & -0.33 & +1.43 \\ 18, \mathrm{CC} & -0.01 & +3.54\end{array}$

$19-4,90-94 \quad-0.89+2.85$

Globigerinoides obliquus

$\begin{array}{llr}19-4,90-94 & -1.60 & +3.10 \\ 20-2,90-94 & -1.84 & +2.90 \\ 20, C C & -1.73 & +2.88 \\ 21-1,90-94 & -1.55 & +3.18 \\ 22-1,90-94 & -1.52 & +2.32 \\ 23-1,90-94 & -1.70 & +2.33 \\ 23-3,90-94 & -1.36 & +2.72\end{array}$

$1-1,0-4$

$1-1,11-12 \quad+1.54 \quad+2.73$

$1-1,90-94+1.68+2.57$

$1-3,90-94+3.11+2.05$

$5-1,90-94+2.84+1.90$

$5, \mathrm{CC}+3.29+2.31$

$6-3,90-94+2.21+2.19$

$6-5,56-58+2.77+2.06$

$7, \mathrm{CC}+2.58+2.08$

$8-1,90-94+2.45+2.50$

$8 . \mathrm{CC}+2.41+1.99$

$9-1,90-94+2.60+0.90$

$9, \mathrm{CC}+2.26+1.17$

$11-3,90-94+2.61+2.01$

$11, \mathrm{CC}+2.52+1.95$

$12-1,90-94+2.58+1.88$

$12, \mathrm{CC}+2.79+1.82$

$13-2,90-94+1.98+0.95$

$13 . \mathrm{CC}+1.92+2.03$

$14-3,90-94+2.09+1.78$

$14, \mathrm{CC}+1.83+1.66$

$15 . \mathrm{CC}+1.76+2.31$

$16-1,90-94+1.99+2.27$

$16-2,90-94+2.11+1.33$

$16-3.90-94+2.04+2.13$

$16-4,90-94+2.08+1.18$

16. CC $+2.02+1.62$

$17-1,90-94+2.33+1.78$

$17-2,90-94+2.45+1.82$

$17-3,90-94+2.30+1.88$

$17-4,90-94+2.36+1.85$

Uvigerina peregrina

$\begin{array}{lll}1-1,11-11 & +3.44 & +1.60 \\ 5, \mathrm{CC} & +4.11 & +0.16 \\ 8, \mathrm{CC} & +4.47 & +0.04 \\ 9-1,90-94 & +3.49 & +0.24 \\ 12-1,90-94 & +4.19 & +0.56 \\ 12, \mathrm{CC} & +3.93 & +0.89 \\ 14-3,90-94 & +3.88 & +0.64 \\ 15, \mathrm{CC} & +3.40 & +0.21 \\ 16-2,90-94 & +4.60 & +0.93 \\ 16, \mathrm{CC} & +3.76 & +0.40 \\ 17-1,90-94 & +4.04 & +0.31 \\ 17-3,90-94 & +3.52 & -0.40 \\ 17, \mathrm{CC} & +4.50 & +0.37 \\ 18-1,90-94 & +4.26 & +0.10 \\ 18-2,90-94 & +3.96 & +0.72 \\ 18-3,90-94 & +4.22 & -0.26 \\ 18, \mathrm{CC} & +4.49 & +0.59 \\ 19-2,90-94 & +3.88 & +0.77 \\ 19, \mathrm{CC} & +3.13 & +0.20 \\ 19, \mathrm{CC} & +2.80 & +0.21 \\ 19, \mathrm{CC} & +3.00 & +0.25 \\ 19, \mathrm{CC} & +3.15 & +0.17\end{array}$


Table 2 (continued).

\begin{tabular}{|c|c|c|}
\hline \multirow{2}{*}{$\begin{array}{l}\text { Sample } \\
\text { (interval in } \\
\mathrm{cm} \text { ) }\end{array}$} & $\delta^{18} \mathrm{O}$ & ${ }_{\delta^{13} \mathrm{C}}$ \\
\hline & \multicolumn{2}{|c|}{$(\% 0$ PDB $)$} \\
\hline \multicolumn{3}{|l|}{ Hole 604 (Cont.) } \\
\hline \multicolumn{3}{|c|}{ Globigerinoides obliquus (Cont.) } \\
\hline $19, \mathrm{CC}$ & +2.88 & +0.22 \\
\hline $19, \mathrm{CC}$ & +3.05 & +0.14 \\
\hline $19, \mathrm{CC}$ & +2.96 & +0.26 \\
\hline $19, \mathrm{CC}$ & +3.12 & +0.26 \\
\hline $20-1,90-94$ & +3.75 & +0.26 \\
\hline $20-2,90-94$ & +2.39 & +0.07 \\
\hline $20, \mathrm{CC}$ & +3.00 & +1.00 \\
\hline $21-2,90-94$ & +3.29 & +0.74 \\
\hline $21-3,90-94$ & +2.89 & +0.86 \\
\hline $21, \mathrm{CC}$ & +2.94 & +0.30 \\
\hline $22-1,90-94$ & +3.37 & +0.21 \\
\hline $22-3,90-94$ & +3.29 & +0.91 \\
\hline $22-5,90-94$ & +2.87 & -0.40 \\
\hline $22, \mathrm{CC}$ & +3.70 & +0.60 \\
\hline $23-1,90-94$ & +3.10 & +0.83 \\
\hline $23-2,90-94$ & +3.14 & +0.69 \\
\hline $23-3,90-94$ & +3.00 & -0.02 \\
\hline $23-4,90-94$ & +3.28 & +0.22 \\
\hline $24-1,2-4$ & +3.22 & -0.01 \\
\hline $24, \mathrm{CC}$ & +2.94 & +0.39 \\
\hline $25-1,90-94$ & +3.00 & +0.83 \\
\hline
\end{tabular}

Unit III (Samples 603C-14-3, 90-94 cm to 603C-2-3, 146-150 cm, CN 12a to the Helicosphaera sellii Zone)

In the last cores of this hole typical glacial/interglacial oxygen isotope variations of $1.5-2 \%$ can be only partly documented because of the large sampling intervals.

The carbon isotope values gradually decrease to about $+1.5 \%$ at the end of the section, pointing to a slow, continuous change in the $\mathrm{CO}_{2}$ budget of surface waters.

\section{Site 604}

Stable isotopes of Uvigerina peregrina and three planktonic foraminifers (Globigerinoides ruber, G. obliquus, and Globorotalia inflata) were analyzed from Site 604 sediments.

\section{Oxygen Isotopes}

Oxygen isotopes of benthic and planktonic foraminifers also reveal the shift to higher $\delta^{18} \mathrm{O}$ values (Samples 604-20-2, 90-94 cm to 604-18,CC; nannofossil zones CN11-12, foraminiferal zones Pl2-4) which was observed at Hole $603 \mathrm{C}$ between 3.7 and $3.0 \mathrm{Ma}(\mathrm{CN} 11 \mathrm{~b}-12 \mathrm{a}$, PI3-4). The first part of this shift seems to occur earlier (P12) at this site than at Hole 603C (Pl3), but this may be an artifact of uncertain age determination and sediment disturbance caused by rotary drilling. The stepwise pattern of this shift, which leads finally to $2 \%$ higher values, can be observed only in the isotopic record of the benthic foraminifer Uvigerina. The isotopic record of planktonic foraminifers does not reveal the different steps, which may also be less pronounced because of fragmentary sampling in this interval. The Pliocene/ Pleistocene section does not show the typical isotopic variation caused by variation in polar ice volumes, for different reasons: drilling disturbance, large sampling intervals, and redeposition caused by turbidity currents (see Site 604-605 chapter, this volume). The only exception to this occurs in the upper part of Core 1 , where a typical glacial/interglacial shift of $\sim 1.7 \%$ in Globorotalia inflata is documented, perhaps indicating the cessation of turbidity currents in the youngest Pleistocene/ Holocene.

\section{Carbon Isotopes}

The lowest part of the Globigerinoides ruber/G. obliquus curve (Samples 604-23-3, 90-94 cm to 604-19-4, 90-94 cm, CN10-12, Pl1a-4) reveals the general shift to higher $\delta^{13} \mathrm{C}$ values which was also noted in Cores 40 to 24 from Hole $603 C$. A shift to a higher value occurs between Section 604-19-4 and Core 604-18, but it is much less pronounced than the one between Section $603 \mathrm{C}$-163 and Core $603 C-15$. However, this is thought to coincide with the beginning of the cooling of North Atlantic surface waters at about 3.0 Ma. Carbon isotopes in Uvigerina, on the other hand, show a slight lightening at this level. The difference in the planktonic and benthic signals has been explained by enhanced productivity of phytoplankton in surface waters (Ganssen, 1983): by this process, light isotopes become enriched in the phytoplankton, enriching surface waters in ${ }^{13} \mathrm{C}$, which is reflected in planktonic foraminiferal tests. At the same time, deeper and bottom waters are enriched in ${ }^{12} \mathrm{C}$ by the oxidation of organic carbon from decaying phytoplankton, which is recorded as a concentration of the light isotope in benthic tests.

\section{CONCLUSIONS}

Hole $603 \mathrm{C}$ oxygen isotopes from Globigerinoides ruber and $G$. obliquus specimens reveal a significant pattern of changing climatic and oceanographic conditions. Three intervals can be identified between the earliest Pliocene and $\sim 1.5 \mathrm{Ma}$. Stepwise enrichment in ${ }^{18} \mathrm{O}$ between 3.7 and 3.0 Ma reveals the cooling of North Atlantic surface waters. This shift can also be documented in the oxygen isotopes from benthic and planktonic foraminifers from Site 604, although in less detail because sediment accumulation rates at this location are lower.

The record of carbon isotopes from Hole $603 \mathrm{C}$ also reflects the three intervals of paleoceanographic and paleoclimatic conditions documented by the oxygen isotope values. Between the earliest Pliocene and $\sim 3.0 \mathrm{Ma}$, a gradual enrichment of about $1 \% 0$ in ${ }^{13} \mathrm{C}$ indicates changes in the dissolved $\mathrm{CO}_{2}$ budget of surface waters. At $\sim 3.0$ Ma a shift to still higher $\delta^{13} \mathrm{C}$ values, on the order of $2 \%$ for planktonic species, initiates a second period of gradual lightening by about $1.5 \%$, up to the youngest sediments recovered. At Site 604 , the gradual change toward higher values in the carbon isotopes of $G$. ruber and $G$. obliquus continues through calcareous nannofossil Zones CN10-12 and planktonic foraminiferal Zones Pl1a-4, whereas results from Uvigerina peregrina document a slight lightening between $\mathrm{CN} 11$ and $\mathrm{CN} 12$, possibly suggesting a general increase in surface-water productivity. 


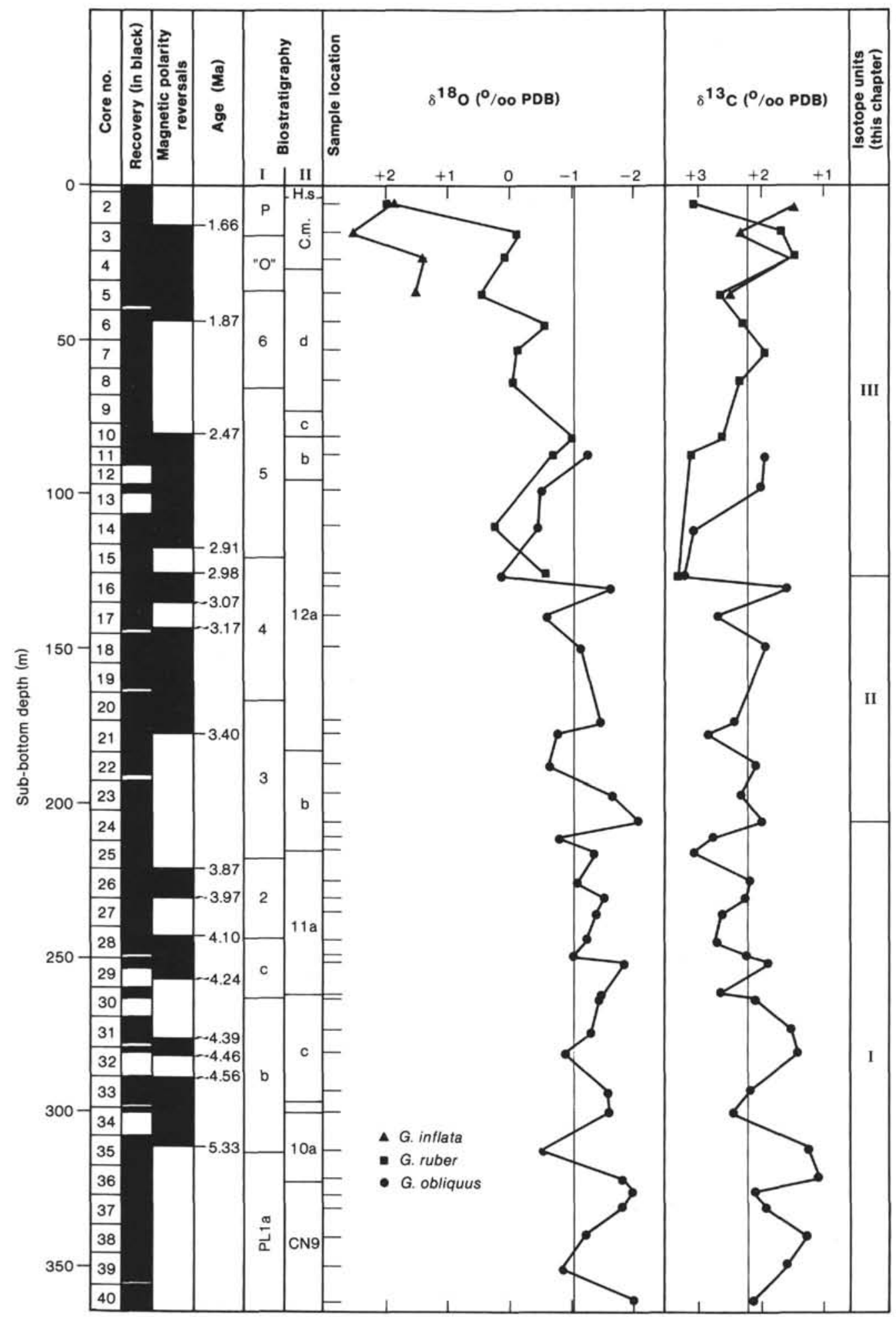

Figure 2. Monospecific oxygen and carbon isotope records for Hole $603 \mathrm{C}$. The solid lines show the mean values of all $G$. ruber/G. obliquus analyses, $-1.02 \pm 0.68 \%_{0}(1 \sigma)$ for $\delta^{18} \mathrm{O}$ and $+2.26 \pm 0.59 \%$ for $\delta^{13} \mathrm{C}$. Magnetostratigraphy and ages from Canninga et al., this volume; black intervals indicate normal polarity. For biostratigraphy, I = planktonic foraminiferal zones from Ma'alouleh and Moullade, this volume; II = calcareous nannofossil zones from Muza et al., this volume, C.m. = Calcidiscus macintyrei Zone, H.s. = Helicosphaera sellii Zone. 


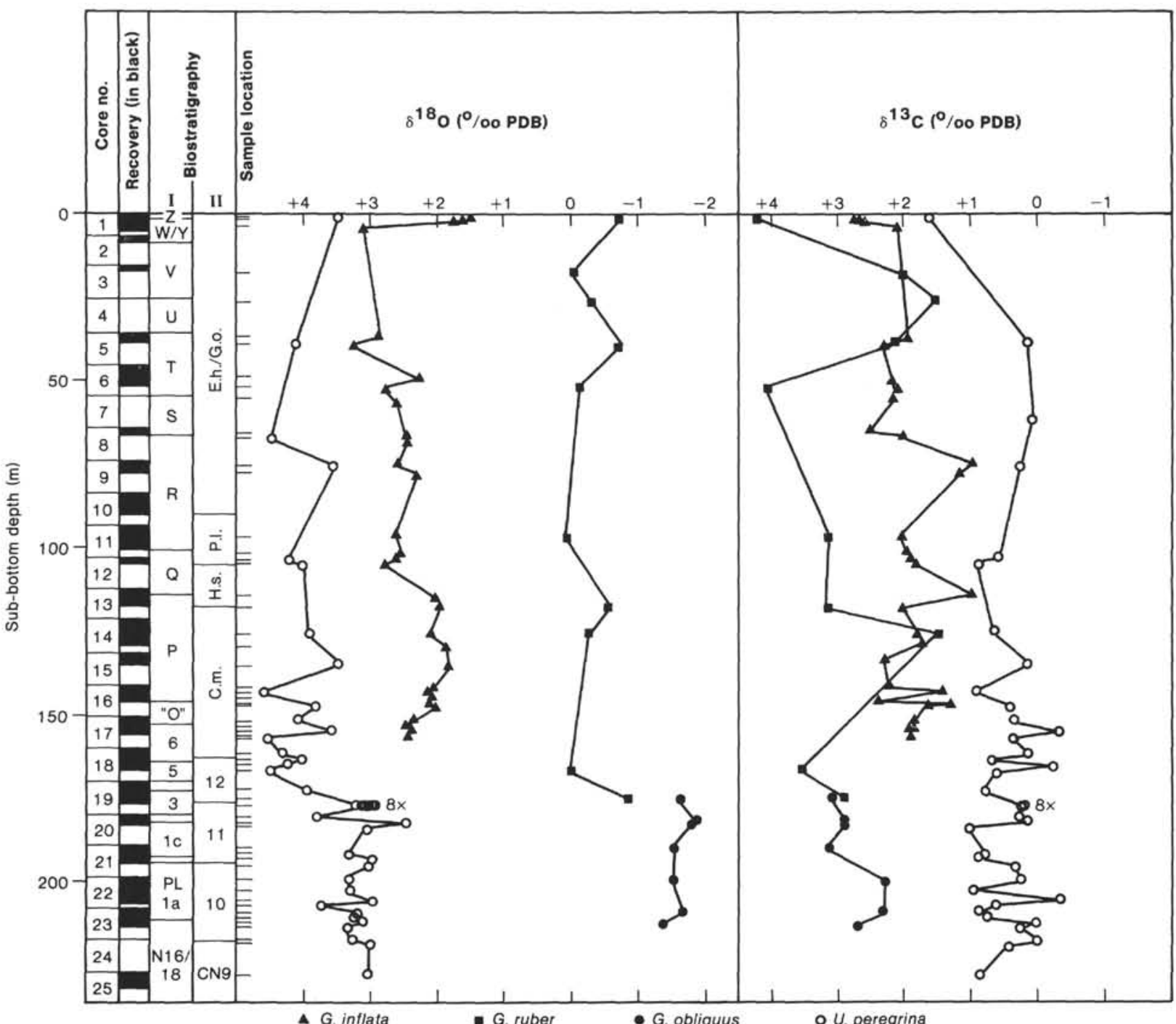

Figure 3. Oxygen and carbon isotope record for Site 604. Biostratigraphy I = planktonic foraminiferal zones from Moullade, this volume; II = calcareous nannofossil zones from Lang and Wise, this volume. C.m. = Calcidiscus macintyrei Zone, H.s. = Helicosphaera sellii Zone, P.1. = Pseudoemiliania lacunosa Zone, E.h. = Emiliania huxleyi Zone, G.o. = Geophyrocapsa oceanica Zone. Note that 8 analyses were made of Sample $604-19$, CC.

\section{ACKNOWLEDGMENTS}

The author would like to thank M. Moullade and his group for providing the material and J. E. van Hinte, J. P. Muza, and W. L. Prell for their suggestions and critical reading of the manuscript.

\section{REFERENCES}

Backman, J., 1979. The age of the first cycle of ice-rafted debris in the North Atlantic Ocean. Terra Cognita, 3 (pts. 2 and 3):221.

Ganssen, G., 1983. Dokumentation von küstennahem Auftrieb anhand stabiler Isotope in rezenten Foraminiferen vor Nordwest-Afrika. "Meteor" Forsch.-Ergebn., C37:1-46.

Keigwin, L. D., Jr., 1979. Late Cenozoic stable isotope stratigraphy and paleoceanography from the east equatorial and central North Pacific Ocean. Earth Planet. Sci. Lett., 45:361-382.

Lowrie, W., and Alvarez, W., 1981. One hundred million years of geomagnetic polarity history. Geology, 9:329-397.

Prell, W. L., 1984. Covariance patterns of foraminiferal $\delta^{18} \mathrm{O}$ : an evaluation of Pliocene ice volume changes near 3.2 million years ago. Science, 226:692-694.

Shackleton, N. J., Backman, J., Zimmerman, H., Kent, D. V., Hall, M. A., Roberts, D. G., Schnitker, D., Baldauf, J. G., Desprairies, A., Homrighausen, R., Huddlestun, P., Keene, J. B., Kaltenback, A. J., Krumsiek, K. A. O., Morton, A. C., Murray, J. W., and
Westburg-Smith, J., 1984. Oxygen isotope calibration of the onset of ice-rafting and history of glaciation in the North Atlantic region. Nature, 307:620-623.

Shackleton, N. J., and Cita, M. B., 1979. Oxygen and carbon isotope stratigraphy of benthic foraminifers at Site 397: detailed history of climatic change during the late Neogene. In von Rad, U., Ryan, W. B. F., et al., Init. Repts. DSDP , 47, Pt. 1: Washington (U.S. Govt. Printing Office), 433-445.

Shackleton, N. J., and Kennett, J. P., 1975. Late Cenozoic oxygen and carbon isotopic changes at DSDP Site 284: implications for glacial history of the Northern Hemisphere and Antarctic. In Kennett, J. P., Houtz, R. E., et al., Init. Repts. DSDP, 29: Washington (U.S. Govt. Printing Office), 801-807.

Stein, R., 1984. Zur neogene Klimaentwicklung in Nordwest-Afrika und Paläoozeanographie im Nordost-Atlantik: Ergebnisse von DSDPSites $141,366,397$ und 544B. Berichte-Reports, Geol. Paläontol. Inst. Univ. Kiel, No. 4:1-210.

Thunell, R. C., 1979. Pliocene-Pleistocene paleotemperatures and paleosalinity history of Mediterranean Sea, results from DSDP Site 125. and 132. Mar. Micropaleontol. 4:173-187.

Date of Initial Receipt: 1 May 1985

Date of Acceptance: 1 April 1986 